\title{
Exposure - for good and ill - in Jonson and Shakespeare
}

\section{Brian Gibbons}

\section{(C) OpenEdition \\ 1 Journals}

\section{Electronic version}

URL: http://journals.openedition.org/shakespeare/1139

DOI: 10.4000/shakespeare.1139

ISSN: 2271-6424

\section{Publisher}

Société Française Shakespeare

\section{Printed version}

Date of publication: 1 November 1997

Number of pages: 27-38

\section{Electronic reference}

Brian Gibbons, "Exposure - for good and ill - in Jonson and Shakespeare », Actes des congrès de la Société française Shakespeare [Online], 15 | 1997, Online since 19 March 2010, connection on 20 April 2019. URL : http://journals.openedition.org/shakespeare/1139; DOI : 10.4000/shakespeare.1139 


\section{EX P O S UR E - F OR GOOODA N D I L L -}

\section{N J O N S O N A N D S H A K E S P E A R E}

My subject is exposure; the theatrical means by which something hidden is made apparent. In Elizabethan drama this can be very straightforward, as in Jonson's comedy Every Man In His Humour. There a would-be gallant Stephano has bought a new sword, a Toledo, and shows it off to the braggart Bobadilla, but Bobadilla is unimpressed : «This a Toledo ? Pish !» Stephano declares he will get his revenge on the scurvy rogue who sold it to him, and at that very moment - what a surprise - enters this same rogue : Stephano addresses him :

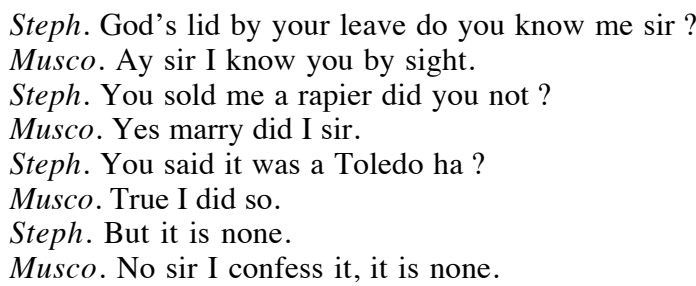

It is comic that agreeing with someone can so completely wrong-foot them. Stephano only deepens his humiliation by further bluster :

Gentlemen bear witness he has confessed it. By God's lid an you had not confessed 
For the audience the main effect here will be the rogue's open confutation of Stephano's ineffectual bluster: Jonson has no interest in Stephano as a character, in any deeper sense of being engulfed in humiliation and embarrassment, in fact Stephano is not up to confronting anything. The point of the episode being to expose Stephano's foolishness and get a laugh, once Jonson achieves it he shifts the audience's attention elsewhere.

An episode from an early Shakespeare comedy, The Two Gentlemen of Verona, III.1, shows the same dramatic structure and technique, though it concerns one of the play's central characters and touches on more complex matters. The young gentleman Valentine tells his best friend Proteus that he intends to elope with Silvia, daughter of the Duke. Proteus duly betrays this plan to the Duke, who then sees Valentine passing in haste, shrouded in a cloak, to put his plan into effect. The Duke detains him and begins a conversation which shows every sign of being prolonged, intimate, and unburdening ; this is in itself embarrassing to Valentine, given his urgent need to get away: and doubly so, given what the Duke starts to tells him. First the Duke divulges, as a secret, that he intends to disown his daughter Silvia for refusing to do as she is told. Valentine replies :

What would your Grace have me to do in this?

The audience knows that the Duke sees through Valentine, so this attempted pose of indifference is seen as fake. The Duke, although obviously old enough to be Valentine's father, asks his advice on how to win a lady, seems undeterred by the remarkably shallow and cynical answers he gets, and then moves in close - embarrassingly close - to Valentine's own situation: how does one reach a lady if she is locked up in a tower? Valentine suggests a rope ladder. The Duke presses him further :

Duke. But hark thee I will go to her alone.

How shall I best convey the ladder thither?

Val. It will be light my lord that you may bear it Under a cloak that is of any length.

Duke. A cloak as long as thine will serve the turn?

Val. Ay good my lord.

Duke. Then let me see thy cloak.

He removes the cloak and exposes Valentine's hidden rope ladder (the longer and thicker the better) and a letter to Silvia. The audience's attention is concentrated on the sight gag and Shakespeare gives Valentine nothing to say at all about how it feels to be thus humiliated - the Duke banishes him and his next speech is all about that. As in Every Man In, once the exposure is effected the playwright directs attention to the next turn in the plot. Still, 
when compared to the Stephano episode from Every Man In, the Two Gentlemen episode is longer, and has a more varied pace and more complex effects : there is a double exposure here : the Duke has the advantages of age and high rank, but in order to manipulate Valentine he has to risk looking like a fool himself in pretending to be in love : it is embarrassing. Valentine, naive and inept, and impatient to get away, has to pretend to be a suave man of the world, not a young twit carrying a rope ladder. The dialogue is susceptible of variations in tone and pace which adds comic potential, but in accordance with the principles of critical comedy Shakespeare reduces the focus to ridicule of Valentine's dishonorable behaviour.

In Measure for Measure and All's Well, where Shakespeare experimentally combined romance with critical comedy, he concentrated on just those emotional implications of exposure which are left latent in Two Gentlemen of Verona. In All's Well the audience is tuned in, as it were, to this unusual form of attention in the early episode (I.3.106-256) when Helena is interviewed by the Countess, whose steward has overheard Helena secretly confess her love for Bertram, the Countess's only son. As Helena enters the Countess observes her shrewdly: but Shakespeare prepares the audience to view the Countess, too, as psychologically interesting, since as she scrutinises Helena she also finds herself moved:

\section{Even so it was with me when I was young}

This sympathy will make the Countess an even better interrogator, and one watches keenly the skill with which she sets Helena up :

Count.

You know, Helen,

I am a mother to you.

$\mathrm{Hel}$. Mine honorable mistress.

Count.

Nay, a mother,

Why not a mother? When I said 'a mother',

Methought you saw a serpent. What's in 'mother',

That you start at it? I say I am your mother.

And put you in the catalogue of those

That were enwombed mine. 'Tis often seen,

Adoption strives with nature, and choice breeds

A native slip to us from foreign seeds.

You ne'er oppressed me with a mother's groan...

At this point Helena is beginning to cry, but if it is a feminine wile it does not deceive the Countess. She hammers home the attack: 
This produces a total dissolution of the young woman's nerve :

$\mathrm{Hel}$. You are my mother, madam would you were So that my lord your son were not my brother Indeed my mother ! ...

$$
\text { Can't no other, }
$$

But, I your daughter, he must be my brother?

The Countess goes in for the kill :

Yes, Helen, you might be my daughter-in-law.

Helena is thus faced with the full extent of her apparent effrontery and deceit, the Countess having anticipated and progressively closed off all her avenues of defence. The audience can enjoy the skill of this manœuvre especially since, having themselves already heard Helena confess secretly, they will have noted that Bertram's high rank is indeed part of his attraction for Helena; yet, on the other hand, did not Helena sound genuinely in love ? The Countess is relentless, so Helena is the focus of critical interest : it is her own self-division that brings her to tearful confusion, and exposes her most secret feelings.

Here in All's Well and in other plays of the period 1598-1606, Much Ado, Hamlet, Measure for Measure, Othello, Shakespeare's characteristic manner of mingling styles acquires this new element of realism. Realism is not satisfactory as a term, and can be improved by going into more detail : it is the dramatist's inclination to build dramatic interest on the tensions of conversation rather than on the suspense of plot, and hence, to create atmosphere by a detailed knowledge of the pressures developing between characters on the stage. The ultimate aim of such a dramaturgy would be when form became a means of expressing experience, rather than idea.

A contrast may also help clarify the issue, and Ben Jonson's plays in the period 1598-1610 provide it, since Jonson, while creating in a series of great plays a wonderful variety of episodes involving exposure and double-exposure (especially the latter in Volpone), yet holds true to the basic model of Every Man In, a critical mode always marked by clear outlines etched in sharp definition. In Volpone there is Sir Politick in his black gloves and cap, crouched in his tortoise-shell, and made to creep in front of the merchants until they spot his garters. In Epicoene a defined effect is evident even in the grand climax that exposes Morose, first, to the fact that the wife he has married is not silent, and second, to the fact that she is not even a woman. In tragedy, in Sejanus, there is the grim farce when, as the letter from Tiberius is read out in the great Senate scene, the senators (like leaves falling from a tree after a sharp frost) shift their seats away from Sejanus to leave the disgraced 
ex-favourite exposed and alone.

In Elizabethan critical comedy plot is not used to represent life but to provide a series of images that bring out moral implications : comic devices are not literal redaction of experience but heightened images, they provide poetic analogies for life. As Shakespeare develops his interest in depicting the emotional and psychological cross-currents that arise between his characters, he nevertheless retains the basic structures of exemplary theatre; as we have seen clearly in All's Well, the tensions of conversation display detailed knowledge of the pressures developing between characters on the stage. Shakespere is sparing in his use of a heightened image or a set-piece to give special emphasis, though when he does so it has the condensed force of poetry - as when Bertram taking his leave for the war ignores the growing distress of his bride Helena, so that she has to ask tearfully for a farewell kiss, which he refuses; or the grand set-piece later in the war when Parolles is cruelly tricked by his own side : he is captured and blindfolded and, unaware that his captors are his own comrades, shamefully slanders and betrays them. They then remove his blindfold and force him to acknowledge them, one by one.

A recent play about the ironies of spying and state treachery in our own times, Alan Bennett's A Question of Attribution is instructive for its combination of realistic style with structures and conventions of critical comedy. Bennett's play concerns the public exposure, as a Soviet spy, of Sir Antony Blunt, Director of the Courtauld Institute and Keeper of the Queen's Pictures. Photographs, both the ordinary kind and x-ray, are an important visual feature of the staging while also constituting the play's centra metaphor, which is exposure. Photographic slides are transparencies which at the same time signify, and x-rays make outer surfaces transparent while exposing what is hidden within. In the television version of A Question of Attribution, the opening sequence shows Blunt undergoing computer tomography and $\mathrm{x}$-ray photography; the viewer sees the resulting exposures, which, as the doctor explains, show that there is nothing amiss with Sir Antony Blunt. The doctor is more interested in the Queen : "What's she really like?» he asks.

I want to draw attention to a significant staging technique, an emblematic entrance, which the dramatist stresses by its effect of interruption. It is a familiar device in the Shakespearean theatre, which Bennett has stolen. Blunt is delivering an art-history lecture illustrated by slides of paintings of annunciations and martyrdoms, when an interruption occurs - it is the entrance of his interrogator from MI5, the secret service :

About suffering they were always wrong, the Old Masters. In Bellini's Agony in the Garden, for instance, the apostles, 
oblivious to all considerations save those of perspective, are fast asleep on ground as bare as an end of the season goalmouth, this sleep signifying indifference. Above them on a rocky promontory of convenient geology Jesus kneels in prayer, an exercise that still goes on in some places.. And here is goes on in some places... And here 1 crucifixion, which we do not do. Or do
differently. Or do indifferently. It is a world in which time means nothing, the present overlaps the future, and did the saint but turn his head he would see his own martyrdom through the window.

(BLUNT turns and on the other side of the stage, right, enter a man in a trilby and raincoat carrying a briefcase. This is $C H U B B)$

Much more is being interrupted than just a lecture here. The comic incongruity of this figure, the MI5 man, Chubb, ironically contrasts with the grim threat he represents to Blunt. The discrepancy between the upper-class Blunt and this lower-middle-class secret service agent exemplifies several ironies of the English class system, not least that Cambridge snobbery is deep enough to survive even dedication to Communism. But it is the precariousness of the relationship between Blunt and Chubb that is its theatrical strength: Bennett conveys it in a subtly degraded comedy of manners, so that - also subtly - nothing ever quite intensifies to full exposure. Blunt's answers to interrogation consist of nothing but negatives, and the relativity of his guilt is left implicit in the undeveloped nature of those negatives.

In dramatic situations of this kind, where one character subjects another to subtle critical observation with the aim of exposure, their psychological relationship is analogous to that of the spatially separated overhearer and person overheard, the observer and person observed. This marking of relationship by physical space is the simplest dramatic method: Shakespeare rapidly develops variations where the observer is baulked of certainty and ambivalence prevails. In Hamlet, although exposure-episodes are repeatedly set up by Hamlet - and by his enemies - the fluid and subtle dramatic atmosphere of this play seems to make it difficult for either side to score a clear hit: indeed in Hamlet recourse to straightforward eavesdropping begins to look clumsily predictable, rather stagey, half-comic. In the bedchamber scene when Hamlet unhesitatingly skewers the eavesdropper behind the arras, 
the joke is on the Prince for thinking this was the King, as well as on Polonius the would-be secret agent, ever unable to avoid being the butt of parody, and finally suffering death by theatrical cliché.

The element of ambivalence and the interest in obscure motive which are general features of Hamlet, are no less evident in double-exposure episodes where the perpetrator, as well as the victim, may be at risk. When the revelation is intimate and sensitive or shameful, the act of eavesdropping has a voyeuristic element which is unsavoury - something evident when Troilus observes Cressida with Diomed, or in All's Well when the trick on Parolles proves so unexpectedly uncomfortable for everyone when they have to listen to him slandering and betraying them.

Let us now turn to the complex sequence of eavesdropping and exposure in Othello IV.1 that climaxes in the entry of the Ambassador from Venice, Lodovico. The idea that Desdemona has played false with Cassio is already agitating Othello when he enters with Iago for Act IV scene 1, and within forty lines Iago has brought him to a paroxism :

Pish! Noses, ears and lips. Is't possible? Confess? Handkerchief? devil!

He falls unconscious. As Iago kneels to revive him, enter Cassio. The audience can reflect that had Cassio only entered half a minute earlier, or half a minute later, he could have told Othello the plain truth ; as it is, Iago takes control and tells him to withdraw a little while - it proves just enough time to set up Othello to eavesdrop Cassio's «confession». Iago exploits Othello' keen sense of anticipation by feeding him in advance with an interpretation of what he is to see : as eavesdropper Othello is to be out of earshot, so Iago directs especially that Othello «mark» Cassio's «gesture». Viewing it all from concealment, Othello duly interprets gesture as exposing Cassio's guilt : «Look how he laughs already! ... Iago beckons me; now he begins the story ... Now he tells how she pluck'd him to my chamber» - at this point, by a telling coincidence, comes the interruption of Bianca's entrance. It is an emphatic - indeed an emblematic - entrance, since the scene's ironic subject is the masculine fantasy which substitutes a whorish image for the true Desdemona.

Bianca is furiously determined to make Cassio take the handkerchief back : "This is some minx's token, and I must take out the work ? there give it your hobby-horse». Iago is taken completely by surprise : then he realises he has no need to intervene: nothing even he could have devised could better have suited his purpose than Bianca brandishing the handkerchief. This unwittingly proves the coup de grace for Othello : 
By heaven, that should be my handkerchief !

Iago gets rid of Cassio and Bianca. Just to make sure Othello did interpret the gestures «quite in the wrong» he calls to him: «Did you perceive how he laugh'd at his vice ? ... And did you see the handkerchief ?».

Iago's playlet with Cassio has a very simple design and he directs the audience to read it simply : as Cassio shall smile, Othello shall go mad ; but we should notice that from the theatre audience's point of view the episode is far from simple. It grimly exposes in Iago's skilful performance new levels of his malignity, but there is something comic exposed too when we see that he is surprised by Bianca's entry, and there is more comedy in the further surprise as he sees how perfectly her intervention is fitting his plot. Othello's inability to hear Cassio makes him appear a fool ; wheras Cassio's inability to see Othello makes him appear foolish too: the symmetry is also reminiscent of comedy. Then Bianca's entry adds a comic effect in openly showing up an embarrassed Cassio : can this be Cassio's supposedly doting Bianca, the one whom Cassio has just been imitating for Iago's amusement, hanging and lolling and weeping upon him ? Nevertheless there is nothing comic about Bianca's effect on Othello, it is decisive. It confirms his fear that Desdemona has shamed him, and that this cannot be kept secret. The accidental coincides with the fatal. The episode is a cunning wrought perspective that shows from one side grotesque comedy, from the opposite side hell :

I will chop her into messes. Cuckold me !

And yet the scene is not done yet; a plan is no sooner sketched Othello to strangle Desdemona in her bed, Iago to take care of Cassio when another interruption occurs :

'Tis Lodovico -

This comes from the Duke. See, your wife's with him.

Iago spells it out so pointedly we may infer that he fears Othello is overwrought - he needs warning to sleek o'er his rugged looks. Certainly this is an emblematic entrance, emphasised by its interrupting effect, and bespeaking in Lodovico the authority of Venice reimposing itself on the anarchy in Cyprus. Othello takes the Duke's letter and goes a little apart to read it - apart enough for the others to begin a conversation without disturbing him, yet close enough for him to overhear some of it. This spatial separation of Othello (stressed by implicit stage directions in the dialogue) serves ironically to recall for the audience, possibly for Othello too, his 
separation when eavesdropping on Cassio a few minutes previously. The implicit parallel in the situations may subliminally work on his overheated imagination : even without Iago's prompting he now interprets what is said as another playlet of exposure, this time of Desdemona.

I want to concentrate on the way Shakespeare first keeps apart and then twines together two distinct matters here, the letter from the Duke and Desdemona's saying she bears love for Cassio. What gives Othello concealment as he overhears Desdemona is the letter from Venice; he persists in apparently reading this letter after beginning to eavesdrop, so that his first exclamations at her are taken as reactions to what he sees in the letter rather than what he hears her say (what he hears her say is «the love I bear for Cassio»). That Othello's plan to murder Cassio for cuckolding him should be interrupted by the letter decreeing Cassio as his replacement, is a coincidence extreme enough for a farcical comedy. To Othello, this final coincidence seems too great : is not this a cunning Venetian joke at his expense ?

Torn by the final evidence, seemingly certain, that Desdemona has just exposed herself as whore, Othello strikes her. It is a memorable heightened stage image ; to Othello it signifies an act of justice, but the witnesses from Venice seem to be interpreting it as the opposite. Very well, he must demonstrate it more explicitly. Lodovico must be made to see how Desdemona is false. He calls her back and manhandles her to make her mechanically perform each movement and gesture :

\section{Sir, she can turn, and turn ; and yet go on} And turn again.

This is another ugly stage image but, more significantly, it replays in caricature form exactly the device of exposure which has been a repeated feature of the scene, except that this time no double meaning is exposed: Othello sees what Iago has taught him to see, and he is convinced by what is exactly not there to see : the metaphoric sense of «she can turn, and turn» that is, he is convinced, he «sees», that Desdemona will serve anyone's turn, whereas he, Othello, honourably obeys his master's command from Venice. In his mind the two ideas, that she is false and he is true, are clear, but as he expresses them his audience hear only confusion:

I am commanded home. - Get you away ;

I'll send for you anon. - Sir, I obey the mandate,

A n i lr le $\mathrm{t}$ utr aV e n i ce H e n cavaunt! (Exit

Desdemona)

Othello makes his exit with the line : 
You are welcome, sir, to Cyprus - Goats and monkeys !

This divided utterance, half to Lodovico, courteous, half to himself, savage, suggests he is on the point of falling into another fit.

In this long scene the device of the playlet is used varyingly by Shakespeare to exhibit different kinds of conscious and unconscious exposure and self-exposure : as a device it works so well for Iago, but then after Lodovico arrives further coincidences trick Othello into believing that the exposure-process is repeating itself spontaneously and unaided, and he expects everyone to share his view that what happens is an exposure of Desdemona. When they do not recognise this, he offers the ugly explicit pantomime of turning Desdemona round like a puppet. It is an unconscious parody of how Iago has manipulated him; and at the same time it is a culminating image : it isolates the different senses in which both Desdemona and Othello are exposed as objects of mingled shame and pathos. It is its concentration of contradictory and incompatible elements that results in Othello's attempted exposure going horribly wrong, so wrong that it is almost intolerable to watch ; Lodovico cannot bring himself to speak about what he has seen.

If Shakespeare in IV.1 of Othello concentrates especially, as we have seen, on the exposure device in terms of outward gesture, in Measure for Measure he also deploys it to explore other, less clearly defined areas of personality. A central question in this play is the Duke himself, who begins by claiming detachment as he dons the disguise of Friar but is rapidly drawn in, as he is exposed to events and involved with other people. The question is, to what extent is a process of change to be inferred in this figure whose chief characteristic is evasiveness ? He is claimed by Lucio to be a «fantastical Duke of dark corners», but he says of himself that his bosom is immune to the «dribbling dart of love». Act IV builds to a crisis in the Duke-as-Friar's somewhat recklessly improvised intrigue, and IV.3 is the scene which concerns his efforts to acquire a freshly severed head, in the middle of the night, as substitute for that of the condemned Claudio, who is due to die at dawn.

The Duke is thus faced with the consequences of his strange decision at the play's beginning, which was to hand government over to the untried deputy Angelo and assume the disguise of Friar to eavesdrop on his own citizens. What the Duke-as-Friar hears and sees would trouble anyone's conscience, but he is quite sparing in self-accusation. It is true that his disguise has to be kept up, and that Shakespeare's plot keeps his mind concentrated on counter-plotting; but there are other characters to keep the issue of the Duke's morality a live one, none more so than Lucio, with whose unexpected emblematic entrance I am now concerned. 
The equivocal nature of eavesdropping is made apparent by the Duke's choice of a disguise ; a Friar's holy vows after all entitle him to hear secret confession, not as he is a fellow human being, but as he is ordained a priest. The first time the Duke-as-Friar presumes to offer sacred comfort, it is to Claudio's wife, and there he is embarrassed by getting rapidly out of his depth. His next eavesdropping is on Claudio and his sister Isabella, which seems equivocal in more complex ways. Theirs is an extremely painfu encounter, in which Claudio hysterically acknowledges his terror but Isabella hysterically refuses to admit the turbulent sexual component in her own anxiety. The theatre audience, already aware of how Isabella's high-minded pleading has had the power to sexually arouse the deputy, may legitimately wonder whether it is having a similar effect on the Duke. Will they think it significant that the Duke-as-Friar promptly disposes of Claudio - «tomorrow you must die, go to your knees and make ready» - but then draws Isabella aside for a confidential conversation of almost one hundred lines ? Turning now to IV.3, the Duke-as-Friar has suffered a succession of embarrassments in prosecuting his schemes, culminating in near-despair when the prisoner Barnardine refuses to agree to have his head chopped off to suit a ducal plot, a refusal which - interestingly - exposes how great is the Duke's surge of interest in saving Isabella's brother, and a refusal that also exposes how callous the Duke can be, how selectively tender.

Shakespeare particularly identifies callousness with Angelo and, less severely, with Lucio, a figure he did not find in the sources but invented specially, a go-between in whom parallels between different parts of the play are made apparent. It is Lucio who first brings news to Isabella in the conven that Claudio is arrested, and who ironically glances at her sexual attractiveness in such a setting; it is Lucio who encourages her to grow passionate in pleading to Angelo for Claudio's life ; it is Lucio who later in the play points out to the Duke-as-Friar that the Duke's deputising his power on Angelo was «a mad fantastical trick» and that decreeing death for fornication is itself an act of sexual perversion. The Duke-as-Friar reacts intemperately to this : is this part of the Friar-disguise, or does it betray the Duke's private disturbance at Lucio's near-miss diagnosis of himself ? At any rate Lucio shows intuition in presenting these ideas in just these terms to this Friar. And now it is Act IV scene 3, it is not yet dawn and by sheer chance a substitute head has been found instead of Barnardine's, Mariana has - it is to be presumed - consummated the bed-trick with Angelo, and Isabella arrives at the prison. The Duke sees an opportunity here to keep her in suspense in order to create a better sensation in the end :

She's come to know

If yet her brother's pardon be come hither. 
But I will keep her ignorant of her good,

To make her heavenly comforts of despair,

When it is least expected.

So he tells Isabella that Claudio's «head is off, and sent to Angelo» but reassures her that the Duke will return «tomorrow» and she can get justice then. Isabella has burst into tears - to be expected after being so bluntly told her brother is beheaded - and the Duke-as-Friar is engaged in tenderly helping her dry her tears when they are suddenly interrupted - it is Lucio. This is an emblematic entrance in the sense that what Lucio sees is the «Friar» and Isabella in apparently intimate physical proximity. To the audience the superimposed image of Lucio brings other matters to mind : Lucio's intuitive awareness of submerged sexual currents, his insistence on the Duke's dubious sexual past, his candour in recognising Isabella's erotic potential. Shakespeare times Lucio's entry to give embarrassment to the Duke and Isabella: whatever view one ultimately takes of the Duke, Lucio's entry and his characteristic gaze exposes them to critical scrutiny: nothing definite is exposed, but Lucio's entry and his greeting «Good even» (which allows an interesting range of possible tone and insinuation) focuses the spectator's mind on the decisive questions about the Duke and Isabella at a crucial turning point of the play. It is entirely characteristic of Measure for Measure that nothing here is concluded, but on the other hand a great deal is subtly exposed.

Brian GIB BONS

Université de Münster 